\title{
Variation in the key indicators during composting of municipal solid organic wastes
}

\author{
Mayur Shirish Jain*, Mohit Daga and Ajay S. Kalamdhad
}

\begin{abstract}
High moisture content in organic wastes leads to a leachate production. Vegetable waste is one kind of municipal solid organic wastes holding very high moisture (88-94\%) and thus becoming nuisance to the environment. Composting is a viable technology to treat such organic waste. This research mainly deals with the insight on physic state of composting during composting of vegetable wastes added with the inoculum and bulking agents. This study showed the attainment of thermophilic stage $\left(65-70^{\circ} \mathrm{C}\right)$ during the composting process and completed with the pathogen-free end product. The bulk density increased from 312 to $380 \mathrm{~kg} \mathrm{~m}^{-3}$ and was well within the recommended range (less than $1000 \mathrm{~kg} \mathrm{~m}^{-3}$ ). The electrical conductivity of the end product was also within the mentioned range $\left(<4 \mathrm{dS} \mathrm{m}^{-1}\right)$. On evaluating the Pearson's correlation coefficient matrix amongst physical parameters, the moisture content and the free air space exhibited positive relationship.
\end{abstract}

Keywords: Vegetable wastes, Composting, Bulk density, Free air space, Statistical correlation

\section{Introduction}

Composting is the degradation of organic wastes in the presence of oxygen. It is one of the best biological treatment that converts waste into a useful compound known as compost. It is an eco-friendly, inexpensive and viable process for organic waste management. It naturally improves the handling characteristics of organic wastes by reducing its volume and weight [1]. Composting process is regulated by the fundamental environmental factors such as temperature, moisture content, $\mathrm{pH}$ and aeration and some characteristics (such as $\mathrm{C} / \mathrm{N}$ ratio, particle size and nutrients) of organic wastes [2].

Organic wastes such as vegetable wastes possess higher moisture content (88-94\%) and slightly acidic $\mathrm{pH}$ (5.1) as characterized in this study. Around $50 \mathrm{Mt}$. of waste is being produced due to the disposal of vegetables and fruits that causes the major environmental pollution at municipal dumpsites [3]. Previous study reported that vegetable wastes decomposes naturally and produces organic acids [4] and leachate that may cause detrimental effects on water bodies. Moreover, disposal in municipal

\footnotetext{
* Correspondence: mayur.jain0111@gmail.com

Department of Civil Engineering, Indian Institute of Technology Guwahati, Guwahati 781039, India
}

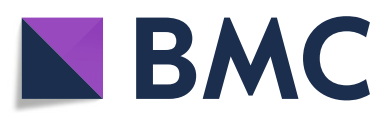

(c) The Author(s). 2019 Open Access This article is distributed under the terms of the Creative Commons Attribution 4.0 International License (http://creativecommons.org/licenses/by/4.0/), which permits unrestricted use, distribution, and

reproduction in any medium, provided you give appropriate credit to the original author(s) and the source, provide a link to the Creative Commons license, and indicate if changes were made. The Creative Commons Public Domain Dedication waiver (http://creativecommons.org/publicdomain/zero/1.0/) applies to the data made available in this article, unless otherwise stated. composting process is a proven, safe and economical way to manage these organic wastes. Previous studies also found the composting of vegetable wastes and its application in the soil [5-7]. Varma and Kalamdhad [3] observed that the moisture content and leachate production have the adverse effects on the properties of the compost with the significant loss of micro-nutrients and heavy metals during composting of vegetable waste. Feasible composting condition may avoid the leachate production, thus achieving the success of compositing process. An application of immature compost may inhibit the seed germination and arrests a growth of plant [8]. The efficiency of the process and the degradation rate of the organic wastes is enhanced by providing the adequate aeration in the composting mixtures [1]. Bulking agents are known to be the best materials to achieve the feasible composting conditions by distributing an optimum aeration required for the complete process.

The primary function of the bulking agents is to absorb an excess moisture content during the composting process, in addition to maintaining the carbon: nitrogen ratio in a feedstock. It not only enhances the microbial activity but also adjusts the porosity of a raw material 
and thus improves the overall aeration [9]. Several researches have been carried out on the effect of bulking agents during the composting of various types of sludges (sewage and industrial sludge) using distinct composting methods $[10,11]$. An experimental study was also performed to evaluate the effect of bulking agents during the composting of municipal wastes and animal manure [12]. Earlier researches have demonstrated the effect of bulking agents on biological/chemical properties and gaseous emissions. However, rarely the literature is lacking on the physical state of composting or variation in the physical parameters such as bulk density (BD), porosity, free air space (FAS) during a rotary drum composting of vegetable wastes added with inoculum and bulking agents. The higher moisture content in the vegetable wastes can have an adverse impact on the rate of microbial growth during the composting process. There is a need to provide a better insight on the variation in physical properties during the decomposition of a vegetable waste added with the inoculum (cow dung) and bulking agents (sawdust and dry leaves). The parameter variation in the temperature, moisture content reduction, and other physical parameters (that controls the entire composting process such as $\mathrm{BD}$, porosity, FAS, and particle density) along with the variation in thermal properties (such as a specific heat capacity) needs to be monitored and evaluated during the composting process.

The physical parameters provide a better insight on the availability of water and oxygen that are vital for the survival of micro-organisms during the composting process. The higher amount of moisture content causes leachate production thus reduces the porosity and oxygen during composting. The favorable moisture content required for the biological decomposition lies between 50 and 70\% [13]. According to Haug [14], FAS should be more than $30 \%$ in the end product. The sufficient air flow can be supplied by the bulking agents to improve the structural and functional properties during the composting process. Bulking agents change the biodegradation kinetics and the overall performance of composting process [15]. Mohee and Mudhoo [16] reported the strong relationship amongst physical parameters that may cause a significant change in the quality of an end product of composting. No such studies carried out during composting of vegetable wastes mixed with the inoculum and bulking agents in high capacity $(550 \mathrm{~L})$ rotary drum composter.

The novelty of this research work is to study the physical state of composting or variation in physical parameters during rotary drum composting of vegetable waste mixed with inoculum and bulking agents. Hence, this study aims to determine: (1) how the combined addition of bulking agents and inoculum affects composting during the composting of vegetable wastes; (2) how these additions improvise the chemical and nutritional quality of the final compost; and (3) what are the correlations among various physical parameters.

\section{Materials and methods \\ Composting reactor, materials, and process}

Experiments were carried out at Indian Institute of Technology Guwahati, Guwahati, Assam, India. The composting study was conducted in $550 \mathrm{~L}$ rotary drum composter that was operated in a batch mode. It is an in-vessel technology, horizontally aligned, cylindrical in shape, and partially opened on both sides to maintain aerobic conditions. Rotary drum composter was mounted on four rubber rollers attached to a metal stand and was rotated manually with lever provided at one end. The inner portion of the drum was welded longitudinally using $40 \times 40 \mathrm{~mm}$ angles, to confirm the suitability of agitation and mixing of wastes through the rotation. The vegetable waste was collected from IITG boys hostel $\left(26^{\circ} 11^{\prime} 26^{\prime \prime} \mathrm{N}\right.$; $91^{\circ} 41^{\prime} 32^{\prime \prime}$ E) Guwahati, Assam, India. Fresh cow dung and sawdust were collected from a nearby dairy farm and sawmill, respectively, located in Amingaon, Guwahati, Assam, India. An inoculum (cow dung) was added to achieve the faster degradation whereas sawdust was mixed with an inoculum to avoid the formation of lumps. Prior to composting, the larger size vegetable wastes were shredded to the size of $1-2 \mathrm{~cm}$, to achieve a better aeration and moisture control. The materials were shredded by means of mechanical shredder equipped with $3.5 \mathrm{~kW}$ motor. The compost mixture was prepared by mixing vegetable waste $(60 \mathrm{~kg})$, cow dung $(30 \mathrm{~kg})$ and sawdust $(10 \mathrm{~kg})$ with the ratio of 6:3:1 as optimized by Varma et al. [17] thus constitutes $100 \mathrm{~kg}$ as total weight. The amount of $10 \%(\mathrm{w} / \mathrm{w})$ dry leaves, selected to be the locally available bulking agents, by total weight was added to the mixture of $100 \mathrm{~kg}$. After, the feedstock's were fed to a rotary drum composter, the composting was carried out for $20 \mathrm{~d}$. The study was conducted at an indoor ambient temperature. The drum was rotated once daily manually to aerate and agitate the compost feedstock. The initial characteristics of physical properties of the various experimental materials are shown in Table 1. Figure 1 shows a pictorial representation of a rotary drum composter used for this particular study.

\section{Sampling, monitoring, and analyses Sampling and monitoring}

The samples were collected ( $300 \mathrm{~g}$ per samples) from the center and two extremities (top, middle, and bottom) from each reactor. Three samples were collected on day $0,2,4$, $6,10,14,18$ and 20 . Then each sample was divided into two parts. One part was oven-dried, ground to pass through a $212 \mu \mathrm{m}$ soil sieve and stored in a vacuumed desiccator. The oven-dried samples were used for the determination of physical properties, $\mathrm{pH}$, electrical conductivity 
Table 1 Characteristics of composing materials used in this study

\begin{tabular}{lllll}
\hline Parameters & $\begin{array}{l}\text { Vegetable } \\
\text { wastes }\end{array}$ & $\begin{array}{l}\text { Cow } \\
\text { dung }\end{array}$ & Sawdust & $\begin{array}{l}\text { Dry } \\
\text { leaves }\end{array}$ \\
\hline Moisture Content (\%) & $89 \pm 2.4$ & $82 \pm 0.5$ & $10.3 \pm 0.2$ & $24.9 \pm 3.5$ \\
Volatile Solids (\%) & $34 \pm 3.3$ & $88 \pm 4.1$ & $65 \pm 1.9$ & $72 \pm 1.5$ \\
$\mathrm{pH}$ & $5.14-5.15$ & $6.50-6.51$ & $6.10-6.11$ & $6.95-6.96$ \\
EC $\left(\mathrm{dS} \mathrm{m}^{-1}\right)$ & $1.9 \pm 0.05$ & $3.4 \pm 0.02$ & $0.6 \pm 0.03$ & $0.6 \pm 0.04$ \\
Bulk Density $\left(\mathrm{kg} \mathrm{m}^{-3}\right)$ & $530 \pm 5$ & $104 \pm 3$ & $375 \pm 13$ & $73 \pm 4$ \\
C/N ratio & $19 \pm 0.3$ & $25.8 \pm 1.5$ & $160 \pm 16$ & $45.2 \pm 1.5$ \\
\hline
\end{tabular}

(EC), particle density, and the contents of volatile solids (VS), total organic carbon (TOC), total Kjeldahl nitrogen (TKN), total phosphorus (P), and total potassium (K). While the other part, which is not oven-dried, was used to quantify the BD, moisture content, and porosity.

Temperatures in the top, middle, and bottom layers of the composting mixtures in the rotary drum composters were monitored using a digital thermometer with a temperature sensor attached to it. Temperature data was collected daily after every 4-h during the entire composting process, and three reading were averaged per composting mix. Ambient temperature was also recorded using the same temperature sensor.

\section{Physical and nutritional analyses}

The moisture content was determined gravimetrically by drying samples at $105^{\circ} \mathrm{C}$ using hot air oven for $24 \mathrm{~h}$. The $2 \mathrm{~L}$ volume mild steel container was used to measure BD. The measurement of BD was carried out in three stages. In first stage the container was filled up to $1 / 3$ rd height and tapped on a plain surface so as to ensure the filling of voids, and in second stage the container is filled

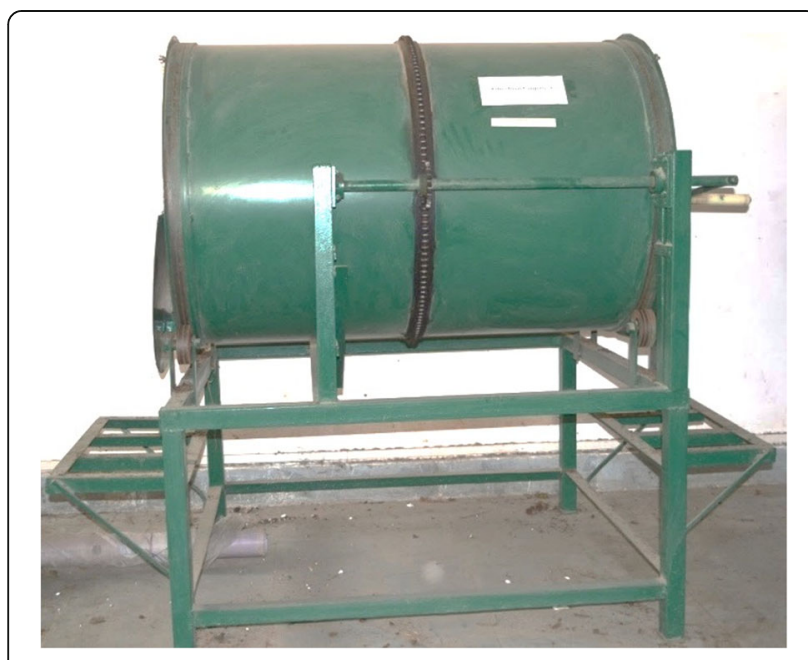

Fig. 1 Photo of rotary drum composter used in this study up to $2 / 3$ rd followed by tapping on a plain surface and in last stage it is filled up to the top brim of the container. BD was calculated as a ratio of the mass of waste $\left(\mathrm{M}_{\mathrm{s}}\right)$ per volume of waste in the container $\left(\mathrm{V}_{\mathrm{c}}\right)$.

$$
\mathrm{BD}=\frac{\mathrm{M}_{s}}{V_{c}}
$$

Particle density (PD), taken as the ratio of the total mass of solid particles to the total volume of solid particles (i.e., excluding water mass and pore or air space) of mix was measured using the $50 \mathrm{~mL}$ density bottle with kerosene $\left(0.78 \mathrm{~kg} \mathrm{~L}^{-1}\right)$ as reference liquid [12]. Porosity $(\eta)$ has been determined using Eq. (2)

$$
\eta=1-\frac{\gamma_{\text {wet }}}{\mathscr{g} \times \gamma_{w}\left(1+\omega_{\mathrm{wet}}\right)}
$$

where $\mathscr{g}=$ specific gravity; $\gamma_{\mathrm{w}}=\mathrm{BD}$ of water; $\omega_{\text {wet }}=$ wet moisture content; $\gamma_{\text {wet }}=$ BD of compost.

The FAS was calculated from the $\mathrm{BD}$ and $\mathrm{PD}$ of the compost matrix using following Eq. (3).

$$
\mathrm{FAS}=100 \times\left(1-\frac{\mathrm{BD}}{\mathrm{PD}}\right)
$$

VS content (weight loss on ignition at $550{ }^{\circ} \mathrm{C}$ ) was determined using muffle furnace. TOC was calculated using Eq. (4) as follows [3].

$$
\% \text { TOC }=\frac{\% \text { Volatile Solids }}{1.8}
$$

The specific heat capacity $\left(C_{p}\right)$ was determined using empirical formula given in study by Keener et al. [18] using Eq. (5).

$$
\mathrm{C}_{\mathrm{p}}=1.48-0.64(\mathrm{ASH})+4.18\left(\mathrm{MC}_{\mathrm{d} . \mathrm{b}}\right)
$$

where, ASH is the mineral content (\%) and $\mathrm{MC}_{\mathrm{d} . \mathrm{b}}$ is the moisture content (\%) in dry weight basis.

$\mathrm{pH}$ and $\mathrm{EC}$ values were measured for waste: distilled water extract ratio of $1: 10(\mathrm{w} / \mathrm{v})$ as per described methods $[3,19,20]$.

TKN was determined by using the Kjeldahl distillation method. Stannous chloride method (acid digestion) was used to find the available and TP [3]. Potassium (K) was determined with a flame photometer by digesting $0.2 \mathrm{~g}$ air-dried $212 \mu \mathrm{m}$ sieved sample with $10 \mathrm{~mL} \mathrm{H}_{2} \mathrm{SO}_{4}$ and $\mathrm{HClO}_{4}(5: 1)$ at $300{ }^{\circ} \mathrm{C}$ for $2 \mathrm{~h} \mathrm{[3].}$

\section{Statistical analysis}

As noted earlier, the samples gathered from individual composting reactors were treated as triplicates for each sampling time and their mean with standard deviation is reported in this paper, which is calculated using Microsoft Excel, 2010. Parsons's correlation 
coefficient was calculated using SPSS 20.0 among various physical parameters.

\section{Results and discussion}

\section{Composting temperature and moisture content}

Temperature is one of the key factors that indicates microbial activity during the composting process. It affects the rate of reactions, and aid in killing harmful pathogens, and plant seeds during the composting process, thus maintaining sanitation capacity of the process [14]. It is predictable that composting process is a four-phase process, consisting of the first as mesophilic phase $\left(25-40^{\circ} \mathrm{C}\right)$, second as thermophilic phase $\left(45-70{ }^{\circ} \mathrm{C}\right)$, then cooling phase (second mesophilic phase), and maturation phase [21]. However, as shown in Fig. 2a, the temperature reached the thermophilic range $\left(45-70^{\circ} \mathrm{C}\right)$ immediately within $24 \mathrm{~h}$ of feeding the rotary drum composter. The optimum temperature range for composting is $40-65^{\circ} \mathrm{C}$ [22]. The maximum temperatures that have been recorded during the current study was $68.9^{\circ} \mathrm{C}$ (on day 2). The study on composting of food wastes mixed with various bulking agents (wheat straw, hay and wood shavings) showed the maximum

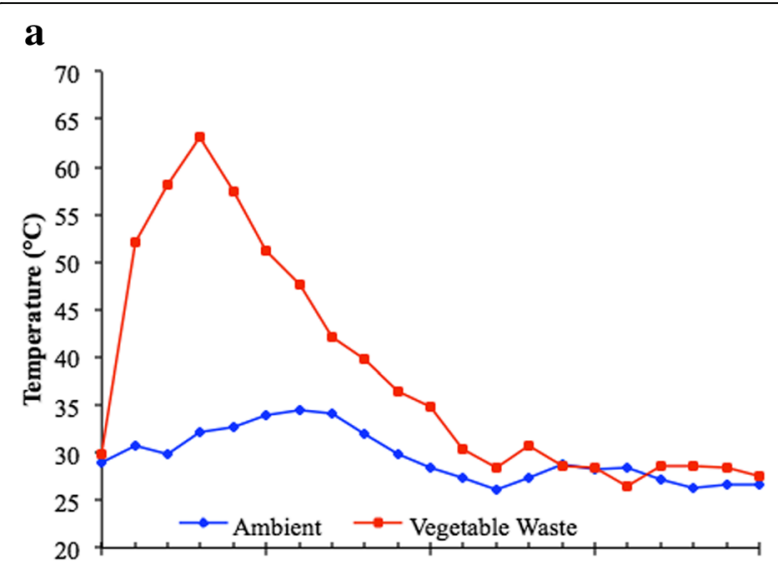

b

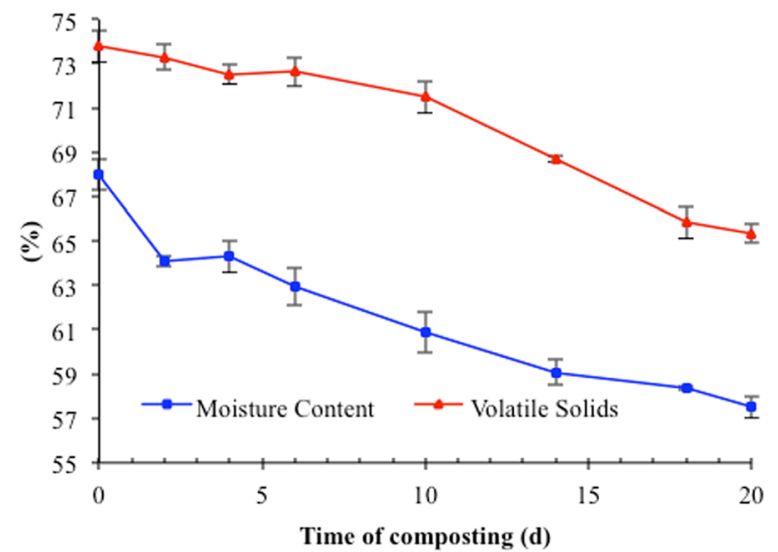

Fig. 2 Variation in (a) Temperature, (b) moisture content and volatile solids during composting temperature of $50^{\circ} \mathrm{C}$ (on day 3) [19]. According to Jolanun and Towprayoon [23], the composting of vegetable wastes mixed with rabbit food and granular materials exhibited thermophilic phase within $6 \mathrm{~h}$ after feeding. In the present study, a thermophilic phase lasts for $6 \mathrm{~d}$ during the composting process. As anticipated, the initial thermophilic temperatures are owing to the addition of dry leaves that delivered appropriate aeration for biological activity. After $6 \mathrm{~d}$ the temperature started declining and it continued falling until the 20th day and was recorded as $27.6^{\circ} \mathrm{C}$, i.e., nearer to ambient temperature. The downward gradient of temperature indicates the slower microbial activity and a lower rate of degradation.

The temperature $55-60^{\circ} \mathrm{C}$ for more than $3 \mathrm{~d}$ is essential during the composting process to obtain a pathogen free compost [24]. The addition of the dry leaves $(10 \mathrm{~kg})$ substantially increased the period of the thermophilic phase that lasts for more than $5 \mathrm{~d}$ during composting process. Similar types of results were obtained during the composting of vegetable wastes [3]. According to Khalil et al. [25], the conventional composting process requires $90-270 \mathrm{~d}$ to produce stable compost. However, in this study the biological activity was observed stable after $18 \mathrm{~d}$, which is indicated by stability in VS reduction on day 20 .

The composting process is greatly affected by environment factors (temperature, moisture content, $\mathrm{pH}$, and aeration) [2]. Moisture content is an essential parameter that influences the changes in physical, chemical, and biological properties of waste materials during the advancement of decomposition of organic matter. Huerta-Pujol et al. [20] reported the moisture content of the mix significantly influences biological activity. In the present study, vegetable wastes were having higher initial moisture content (89\%). Hence, the addition of bulking agents was considered to absorb the excess moisture during composting process. Due to the addition of bulking agents, the initial moisture content of the original mix decreased as tabulated in Table 2. Figure 2b illustrates the decreasing trend for moisture content. Due to the availability of readily biodegradable organic matter, first peak in the temperature $\left(>65^{\circ} \mathrm{C}\right)$ were recorded within $3 \mathrm{~d}$, and no leachate was witnessed during the composting process. As a result of decomposition during composting, moisture content and vapors produces, which were absorbed by bulking agents and trapped in the rotary drum composter [26]. The moisture content of end compost after $20 \mathrm{~d}$ was recorded as $57 \%$. Total $15 \%$ reduction in moisture content was observed due to addition of bulking agents and due to the loss of water through evaporation. Thus bulking agents played a major role in absorbing moisture content and leachate production during the composting process. 
Table 2 The value of compost properties summarized at initial and final experimental periods

\begin{tabular}{lll}
\hline Parameters & Initial mix & Final composts \\
\hline Moisture Content (\%) & $67.9 \pm 0.7$ & $57 \pm 0.5$ \\
Volatile Solids (\%) & $74 \pm 0.7$ & $65.3 \pm 0.6$ \\
$\mathrm{pH}$ & $6.76-6.77$ & $7.75-7.76$ \\
Bulk Density $\left(\mathrm{kg} \mathrm{m}^{-3}\right)$ & $312 \pm 5.4$ & $380 \pm 3.3$ \\
Total Kjeldahl Nitrogen (\%) & $1.54 \pm 0.2$ & $2.24 \pm 0.3$ \\
Available Phosphorus $\left(\mathrm{g} \mathrm{kg}^{-1}\right)$ & $3.41 \pm 0.3$ & $4.35 \pm 0.5$ \\
Specific heat capacity $\left(\mathrm{J} \mathrm{kg}^{-1} \mathrm{~K}^{-1}\right)$ & $29.2 \pm 2.1$ & $37.78 \pm 1.7$ \\
C/N ratio & $24 \pm 0.8$ & $16 \pm 0.9$ \\
\hline
\end{tabular}

\section{Composting VS and TOC}

Previously reported studies showed that the bulking agents acts differently for the reduction of the organic matter during the composting of various wastes which depends on the type and quality of the bulking agent used during the composting process. The addition of recalcitrant organic materials reduces the degradation of the organic matter and enhances the humification and the quality of the final composts [27]. In the present study, the TOC and VS decreased significantly during composting with the maximum reduction occurring during thermophilic phase $\left(>45^{\circ} \mathrm{C}\right)$. The $13 \%$ decrease from the initial TOC value was observed during entire composting process as tabulated in Table 3 . An initial VS was $74 \%$ and reduced to $65 \%$ after $20 \mathrm{~d}$ of composting (Fig. 2b). It was noted that added dry leaves have significantly contributed more organics and VS. Hence, such bulking agents should be reused as Varma et al. [17] stated that the removal of bulking agents from compost could provide a better reduction in organics and VS.

\section{BD, porosity, FAS and PD}

$\mathrm{BD}$ is the critical parameter that optimizes composting process, as it determines the optimal conditions for the microbial development, microbial activity, and organic

Table 3 Variation in total organic carbon, porosity and specific heat capacity throughout composting process

\begin{tabular}{llll}
\hline Days & $\begin{array}{l}\text { Total organic } \\
\text { carbon (\%) }\end{array}$ & Porosity (\%) & $\begin{array}{l}\text { Specific heat } \\
\text { capacity }\left(\mathrm{Jg}^{-1} \mathrm{~K}^{-1}\right)\end{array}$ \\
\hline 0 & $41.0 \pm 0.7$ & $49.2 \pm 0.7$ & $32.1 \pm 0.3$ \\
2 & $40.7 \pm 0.2$ & $48.7 \pm 0.3$ & $36.4 \pm 0.4$ \\
4 & $40.3 \pm 0.3$ & $48.5 \pm 0.7$ & $35.7 \pm 0.1$ \\
6 & $40.3 \pm 0.1$ & $48.3 \pm 0.8$ & $37.2 \pm 0.0$ \\
10 & $39.7 \pm 0.3$ & $48.3 \pm 0.9$ & $39.3 \pm 0.4$ \\
14 & $38.2 \pm 0.5$ & $48.2 \pm 0.6$ & $41.1 \pm 0.3$ \\
18 & $36.0 \pm 0.3$ & $48.2 \pm 0.0$ & $42.1 \pm 0.4$ \\
20 & $36.3 \pm 0.7$ & $48.1 \pm 0.5$ & $43.3 \pm 0.5$ \\
\hline
\end{tabular}

matter degradation [13]. The bulk density is also responsible for the change in various mechanical properties such as strength and porosity [28]. Moreover, bulking agents aid in absorbing excess moisture content from the substrate. Zhang and Sun [29] reported that the bulking agents play a significant role in optimizing BD. They further observed a lesser BD in final compost in the mix with bulking agents compared to that without bulking agents [29]. In the present study, during the composting process, wet $\mathrm{BD}$ was observed to be increasing from 312 to $380 \mathrm{~kg} \mathrm{~m}^{-3}$ and volume reduction was observed to be prominent. It was clear during the thermophilic phase that $\mathrm{BD}$ showed greater increase when compared to the entire duration of process, which was owing to loss of organic matter. Other studies carried out on various organic wastes also showed a similar pattern for BD [16]. The $22 \%$ increment from the initial $\mathrm{BD}$ value was observed during composting process of 20 $\mathrm{d}$ as illustrated in Fig. 3a. The particle size of composting materials also plays an important role in increasing the $\mathrm{BD}$. The study performed on municipal solid waste composts in different particle size fractions indicated increasing $\mathrm{BD}$ with the decrease in particle size of wastes [30]. The study conducted by Jain et al. [31] on composting nitrogen-rich organic waste with biochar as bulking agent also showed increasing trend for the BD during composting process.

Excessive moisture present in the organic wastes causes leachate formation and reduction in the porosity and FAS. Physical parameters such as porosity and FAS are evaluated for optimizing the composting process. FAS should be present more than $30 \%$ for proper aeration during composting process [14]. Bulking agents are carbonaceous material that provides optimal FAS. Moreover, it regulates the moisture content during the composting process. An interesting observation was that despite of $22 \%$ increment in $\mathrm{BD}$, the variation in the porosity was not significant during the entire composting process as shown in the Fig. 3a and Table 2. Bulking agents also increased the pore space [29]. Furthermore, volume reduction after composting revealed that enough pore space was available for microbial activity to degrade the organic matter during the composting process.

FAS is an essential parameter as it measures the magnitude and movement of air through composting mix. Jain et al. [31] reported that ratio of waste to bulking agent could influence the percentage of FAS in batch composting. In the present study the initial FAS was $73 \%$ and reduced to $67 \%$ after $20-\mathrm{d}$ of the composting process (Fig. 3). The initial FAS of $80-90 \%$ showed no adverse effects on the composting process [31]. It also depends on the particle size of the wastes. Therefore, less reduction was observed during the composting process. FAS values for different substrates reported in 


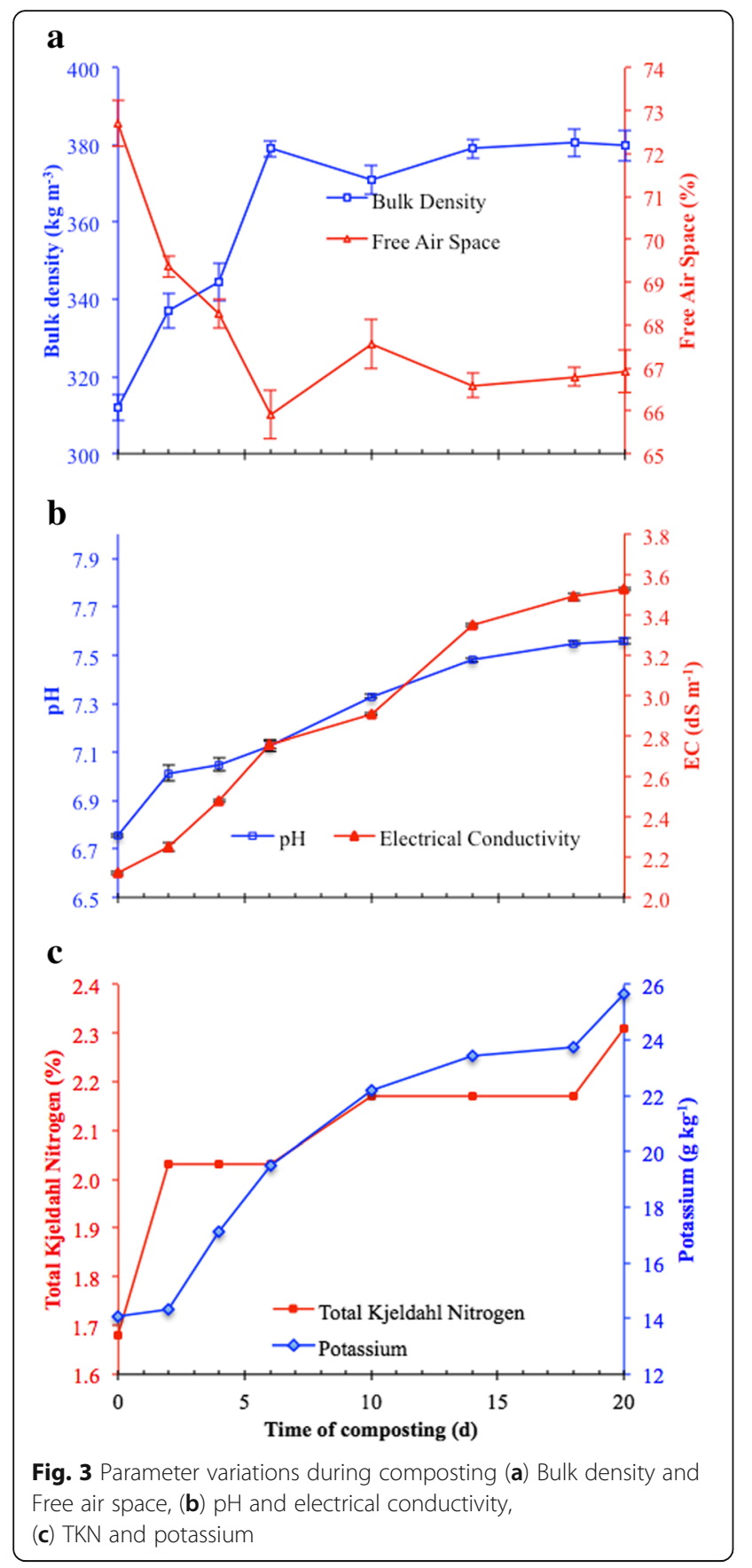

the literature are tabulated in Table 4. All the studies including present study exhibited the recommended values of FAS (>30\%) except for Gabriels et al. [32] that indicated excessive composting aeration during the process.

$\mathrm{PD}$, the average density of all the minerals that available in the compost, is frequently used to calculate the FAS of organic wastes [31]. It also depends on nature and type of substrate used for composting. PD varied from 578 to $687 \mathrm{~kg} \mathrm{~m}^{-3}$ during composting process in the present study. Other studies also reported such small variation during composting process as tabulated in Table 5 .
Table 4 Percentage of free air space occupied in the different compost mixtures at the end of treatment

\begin{tabular}{|c|c|c|}
\hline End compost mix & Free air space (\%) & References \\
\hline $\begin{array}{l}\text { Woodchips, cattle manure and mixed } \\
\text { vegetables }\end{array}$ & 40 & [16] \\
\hline Bark and peat compost & 18.2 & [32] \\
\hline $\begin{array}{l}\text { Five mixtures of garbage, sludge cake, } \\
\text { paper and vermiculite }\end{array}$ & $>30$ & [37] \\
\hline $\begin{array}{l}\text { Vegetable wastes, cow dung, sawdust } \\
\text { and dry leaves }\end{array}$ & 67 & This study \\
\hline
\end{tabular}

However, Mohee and Mudhoo [16] and van Ginkel et al. [33] revealed considerable variation in the PD durng composting process over the period of time. According to van Ginkel et al. [33], PD depends on the change in ash content and VS during the composting process.

\section{Composting specific heat capacity}

The thermal properties such as heat storage capacity, or specific heat, of the bulk material usually influences the amount of material required to maintain the appropriate rise in temperatures [18]. The specific heat capacity is also the function of moisture content. As anticipated, the increase in the ash content was observed with the decrease in the VS contents (Table 3). An increase in ash content directly influences the increase in specific heat capacity during the composting process. Moreover, Rahman [34] revealed a linear relationship between moisture content and thermal specific heat. For current the study, the $16 \%$ increment in specific heat capacity was observed during the thermophilic phase.

\section{Composting $\mathrm{pH}, \mathrm{EC}$ and nutritional properties}

$\mathrm{pH}$ is an important parameter in governing the decomposition process [17]. Biological activities are mostly influenced by the change in $\mathrm{pH}$, and a neutral $\mathrm{pH}$ is recommended to be optimal for the composting process [28]. The $\mathrm{pH}$ showed an increasing pattern during the composting process as illustrated in Fig. 3b. During the initial rise of temperatures, the $\mathrm{pH}$ increased quickly

Table 5 Particle density in the different compost mixtures at the end of treatment

\begin{tabular}{|c|c|c|}
\hline End compost mix & $\begin{array}{l}\text { Particle density } \\
\left(\mathrm{kg} \mathrm{m}^{-3}\right)\end{array}$ & References \\
\hline $\begin{array}{l}\text { Woodchips, cattle manure and mixed } \\
\text { vegetables }\end{array}$ & $1097-2325$ & [16] \\
\hline $\begin{array}{l}\text { Five mixtures of garbage, sludge cake, } \\
\text { paper and vermiculite }\end{array}$ & $1200-1600$ & [37] \\
\hline Wheat straw and chicken manure & $1500-2650$ & [38] \\
\hline Cattle manure & $1750-1820$ & [39] \\
\hline Biosolids compost & $1298-1434$ & [40] \\
\hline $\begin{array}{l}\text { Vegetable wastes, cow dung, sawdust } \\
\text { and dry leaves }\end{array}$ & $578-687$ & This study \\
\hline
\end{tabular}


from 6.8 to 7.1 in the thermophilic phase. Subsequently, increase in the $\mathrm{pH}$ was noted during 20-d composting process. The $\mathrm{pH}$ for end compost was recorded as 7.6. Others revealed that the range of $\mathrm{pH}$ between 7 and 8 supports the microbial activity for the decomposition of organic matter during composting process [29]. In the present study, the $\mathrm{pH}$ was close to the desired optimal range for composting process and in the later stage, $\mathrm{pHs}$ were relatively constant as the composting process ended indicating the stabilization of process and lower microbial activities. Increase in the $\mathrm{pH}$ during the composting process occurs mainly due to activity of proteolytic bacteria and higher buffering capacity of bulking agents avoids further $\mathrm{pH}$ fluctuation [35].

The mineral cation concentration increases with the decomposition of organic materials and is not reduced by binding to stable organic complex [28]. The changes in EC showed a typical trend during the composting process as shown in Fig. 3b. During initial rise of temperatures, the EC increased quickly, or from the initial 2.1 increased to $3.5 \mathrm{dS} \mathrm{m}^{-1}$ during composting. Zhang and Sun [29] reported that addition of bulking agents usually increases the EC values during the composting process as it increases the production of inorganic compounds and the release of ions. The EC value less than 4 is recommended for the compost application in soil.

The bulking agents could enhance organic matter decomposition and hence increase the rate at which ions are released. It may be the reason for an increase in EC during composting added with inoculum and bulking agents.

Nutritional properties such as nitrogen, phosphorus, and potassium were measured during 20-d composting process. It was observed that all nutritional parameters were observed to be increasing during the composting process. The TK concentration was observed to be increased from 14.3 to $25.2 \mathrm{~g} \mathrm{~kg}^{-1}$ during the composting process as illustrated in Fig. 3c. The addition of bulking agents absorbed relatively large amount of moisture and intact structural integrity and porosity could be responsible for preventing the loss of potassium during the composting process. Phosphorus concentration was also found gradually increasing from 3.4 to $4.4 \mathrm{~g} \mathrm{~kg}^{-1}$ during the composting process (Table 2). In the present study, TKN also followed an increasing trend; from the initial value of 1.5 to $2.2 \%$ - an increase by 1.5 -fold during the composting process (Fig. 3c). An increase was due to the addition of bulking agents that absorbed the higher amount of both aqueous $\mathrm{NH}_{4}-\mathrm{N}$ and gaseous $\mathrm{NH}_{3}$ during composting process [36].

\section{Correlations and regression analyses}

Table 6 shows the Pearson's correlation coefficient matrix, representing the relationship among the various
Table 6 Pearson's correlation between physical properties during composting process

\begin{tabular}{llllll}
\hline & & $\mathrm{MC}^{\mathrm{a}}$ & $\mathrm{BD}^{\mathrm{b}}$ & $\mathrm{FAS}^{\mathrm{c}}$ & $\mathrm{PD}^{\mathrm{d}}$ \\
\hline Vegetable wastes, cow dung, & $\mathrm{MC}^{\mathrm{a}}$ & 1 & -0.98 & 0.98 & -0.88 \\
sawdust and dry leaves & $\mathrm{BD}^{\mathrm{b}}$ & & 1 & -0.89 & 0.94 \\
& $\mathrm{FAS}^{\mathrm{c}}$ & & & 1 & -0.95 \\
& $\mathrm{PD}^{\mathrm{d}}$ & & & & 1 \\
\hline
\end{tabular}

Correlation is significant at the 0.05 level (2-tailed)

${ }^{\mathrm{a} M C}$ Moisture content

${ }^{\mathrm{b}} B D$ Bulk density

${ }^{C} F A S$ Free air space

${ }^{\mathrm{d}} P D$ Particle density

physical parameters such as moisture content, FAS, BD and PD as they play the significant functions in attaining a better composting process. A negative correlation coefficient between moisture and $\mathrm{BD}$ was observed to be 0.98; as the moisture decreases, the BD increases. Also FAS was negatively correlated with $\mathrm{BD}$, but positively correlated with the moisture contents of the sample. Thus, a decrease in moisture content decreases the FAS between compost mix.

\section{Conclusions}

The results of the current study signified the scope of additives aided composting process. The moisture content was observed to be $57 \%$ at the end of the composting process, and was within the recommended range. The maximum temperature rise was observed up to $68.9^{\circ} \mathrm{C}$ during composting process. $\mathrm{BD}$ followed the increasing trend during the composting process. The physical parameters such as moisture content, BD, porosity and FAS found to be in the relationship with each other. FAS and moisture content exhibited a positive correlation with an extremely high correlation coefficient $(r=0.98)$.

Authors' contributions

All authors read and approved the final manuscript.

Competing interests

The authors declare that they have no competing interests.

\section{Publisher's Note}

Springer Nature remains neutral with regard to jurisdictional claims in published maps and institutional affiliations.

Received: 2 March 2018 Accepted: 23 January 2019

Published online: 11 April 2019

References

1. Yamada Y, Kawase Y. Aerobic composting of waste activated sludge: kinetic analysis for microbiological reaction and oxygen consumption. Waste Manag. 2006;26:49-61.

2. Silva MEF, de Lemos LT, Nunes OC, Cunha-Queda AC. Influence of the composition of the initial mixtures on the chemical composition, physicochemical properties and humic-like substances content of composts. Waste Manag. 2014;34:21-7.

3. Varma VS, Kalamdhad AS. Effects of leachate during vegetable waste composting using rotary drum composter. Environ Eng Res. 2014;19:67-73. 
4. Chanakya HN, Ramachandra TV, Guruprasad M, Devi V. Micro-treatment options for components of organic fraction of MSW in residential areas. Environ Monit Assess. 2007;135:129-39.

5. Leroy BLM, Herath HMSK, De Neve S, Gabriels D, Bommele L, Reheul D, et al. Effect of vegetable, fruit and garden (VFG) waste compost on soil physical properties. Compost Sci Util. 2008;16:43-51.

6. Montemurro F, Maiorana M, Convertini G, Ferri D. Compost organic amendments in fodder crops: effects on yield, nitrogen utilization and soil characteristics. Compost Sci Util. 2006;14:114-23.

7. Leroy BLMM, Bommele L, Reheul D, Moens M, De Neve S. The application of vegetable, fruit and garden waste (VFG) compost in addition to cattle slurry in a silage maize monoculture: effects on soil fauna and yield. Eur J Soil Biol. 2007:43:91-100

8. Zorpas AA, Loizidou M. Sawdust and natural zeolite as a bulking agent for improving quality of a composting product from anaerobically stabilized sewage sludge. Bioresour Technol. 2008;99:7545-52.

9. Shao LM, Zhang CY, Wu D, Lu F, Li TS, He PJ. Effects of bulking agent addition on odorous compounds emissions during composting of OFMSW. Waste Manag. 2014;34:1381-90.

10. Dias BO, Silva CA, Higashikawa FS, Roig A, Sanchez-Monedero MA. Use of biochar as bulking agent for the composting of poultry manure: effect on organic matter degradation and humification. Bioresour Technol. 2010;101:1239-46.

11. Ucaroglu S, Alkan U. Composting of wastewater treatment sludge with different bulking agents. J Air Waste Manage Assoc. 2016:66:288-95.

12. Adhikari BK, Tremier A, Martinez J, Barrington S. Home and community composting for on-site treatment of urban organic waste: perspective for Europe and Canada. Waste Manag Res. 2010;28:1039-53.

13. Richard TL, Hamelers HVM, Veeken A, Silva T. Moisture relationships in composting processes. Compost Sci Util. 2002;10:286-302.

14. Haug RT. The practical handbook of compost engineering. Boca Raton: CRC Press; 1993.

15. Kulcu R, Yaldiz O. Composting of goat manure and wheat straw using pine cones as a bulking agent. Bioresour Technol. 2007;98:2700-4.

16. Mohee R, Mudhoo A. Analysis of the physical properties of an in-vessel composting matrix. Powder Technol. 2005:155:92-9.

17. Varma VS, Mayur C, Kalamdhad A. Effects of bulking agent in composting of vegetable waste and leachate control using rotary drum composter. Sustain Environ Res. 2014;24:245-56.

18. Keener HM, Marugg C, Hansen RC, Hoitink HAJ. Optimizing the efficiency of the composting process. In: Hoitink HAJ, Keener HM, editors. Science and engineering of composting: design, environmental, microbiological and utilization aspects. Worthington: Renaissance Publications; 1993. p. 59-94.

19. Adhikari BK, Barrington S, Martinez J, King S. Effectiveness of three bulking agents for food waste composting. Waste Manag. 2009;29:197-203.

20. Huerta-Pujol O, Soliva M, Martinez-Farre FX, Valero J, Lopez M. Bulk density determination as a simple and complementary tool in composting process control. Bioresour Technol. 2010;101:995-1001.

21. Diaz LF, Savage GM. Factors that affect the process. In: Diaz LF, de Bertoldi M, Bidlingmaier W, Stentiford E, editors. Compost science and technology. Amsterdam: Elsevier; 2007. p. 49-65.

22. de Bertoldi M, Vallini G, Pera A. The biology of composting: a review. Waste Manag Res. 1983;1:157-76.

23. Jolanun B, Towprayoon S. Novel bulking agent from clay residue for food waste composting. Bioresour Technol. 2010;101:4484-90.

24. Zhang $L$, Sun $X Y$, Tian $Y$, Gong $X Q$. Effects of brown sugar and calcium superphosphate on the secondary fermentation of green waste. Bioresour Technol. 2013;131:68-75.

25. Khalil A, Domeizel M, Prudent P. Monitoring of green waste composting process based on redox potential. Bioresour Technol. 2008;99:6037-45.

26. Jain MS, Kalamdhad AS. Efficacy of batch mode rotary drum composter for management of aquatic weed (Hydrilla verticillata (L.f.) Royle). J Environ Manag. 2018;221:20-7

27. Goyal S, Dhull SK, Kapoor KK. Chemical and biological changes during composting of different organic wastes and assessment of compost maturity. Bioresour Technol. 2005;96:1584-91.

28. Karnchanawong S, Mongkontep T, Praphunsri K. Effect of green waste pretreatment by sodium hydroxide and biomass fly ash on composting process. J Clean Prod. 2017;146:14-9.
29. Zhang L, Sun XY. Influence of bulking agents on physical, chemical, and microbiological properties during the two-stage composting of green waste. Waste Manag. 2016:48:115-26.

30. Zhao SL, Lian F, Duo LA. EDTA-assisted phytoextraction of heavy metals by turfgrass from municipal solid waste compost using permeable barriers and associated potential leaching risk. Bioresour Technol. 2011;102:621-6.

31. Jain MS, Jambhulkar R, Kalamdhad AS. Biochar amendment for batch composting of nitrogen rich organic waste: effect on degradation kinetics, composting physics and nutritional properties. Bioresour Technol. 2018;253: 204-13.

32. Gabriels R, Keirsbulck W, Engels H. A rapid method for the determination of physical properties of growing media. Acta Hortic. 1993;342:243-8.

33. van Ginkel JT, Raats PAC, van Haneghem IA. Bulk density and porosity distributions in a compost pile. Neth J Agric Sci. 1999;47:105-21.

34. Rahman MS. Microcalorimetric Measurement of Heat Production and Thermophysical Properties of Compost [Ph.D. Dissertation]. New Brunswick: Rutgers Univ; 1984.

35. Rich N, Bharti A, Kumar S. Effect of bulking agents and cow dung as inoculant on vegetable waste compost quality. Bioresour Technol. 2018;252: $83-90$

36. Zhang L, Sun XY. Influence of sugar beet pulp and paper waste as bulking agents on physical, chemical, and microbial properties during green waste composting. Bioresour Technol. 2018;267:182-91.

37. Schulze KL. Continuous thermophilic composting. Appl Microbiol. 1962;10: 108-22.

38. Chowdhury MA, de Neergaard A, Jensen LS. Prediction of changes in important physical parameters during composting of separated animal slurry solid fractions. Environ Technol. 2014;35:220-31.

39. Inbar Y, Hadar Y, Chen Y. Recycling of cattle manure: the composting process and characterization of maturity. J Environ Qual. 1993;22:857-63.

40. Das K, Keener HM. Moisture effect on compaction and permeability in composts. J Environ Eng ASCE. 1997;123:275-81.

\section{Ready to submit your research? Choose BMC and benefit from:}

- fast, convenient online submission

- thorough peer review by experienced researchers in your field

- rapid publication on acceptance

- support for research data, including large and complex data types

- gold Open Access which fosters wider collaboration and increased citations

- maximum visibility for your research: over $100 \mathrm{M}$ website views per year

At $\mathrm{BMC}$, research is always in progress.

Learn more biomedcentral.com/submissions 